
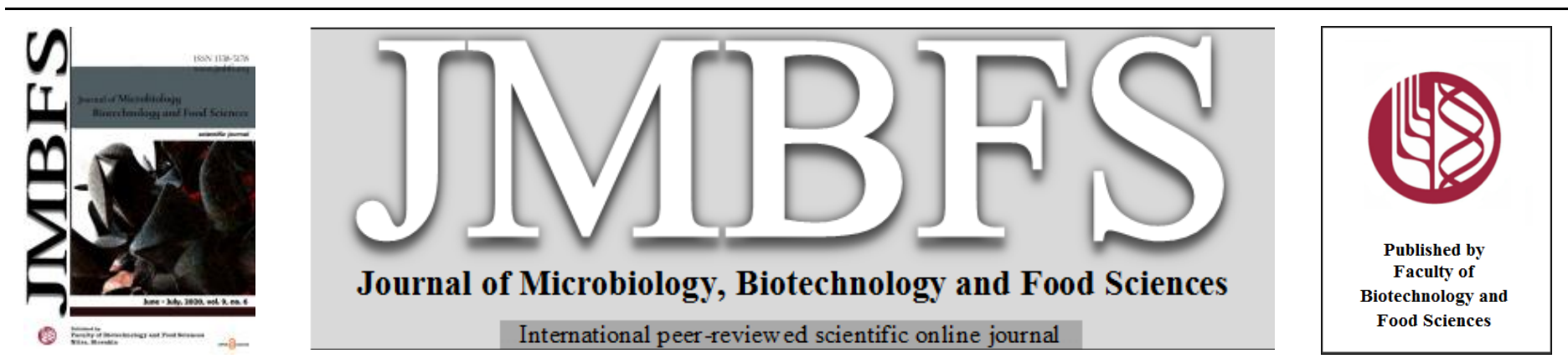

\title{
GENETIC DIVERSITY OF LEPTIN GENE INTRON 2 IN WILD AND NATIVE AND EXOTIC GOAT BREEDS IN IRAN
}

\author{
Narges Esmaeili Aliabad Vazir ${ }^{*}$, Ali Esmaeilizadeh Koshkooieh ${ }^{l}$, Ahmad Aytolahi Mehrjerdi ${ }^{l}$, Mohammadreza Mohammadabadi ${ }^{l}$, \\ Olena Ivanivna Babenko ${ }^{2}$, Maryna Vitaliivna Bushtruk ${ }^{2}$, Serhii Vasyliovych Tkachenko ${ }^{2}$, Ruslana Volodymyrivna Stavetska ${ }^{2}$, Nataliia \\ Ihorivna Klopenko ${ }^{2}$
}

\author{
Address(es): \\ ${ }^{1}$ Department of Animal Science, Shahid Bahonar University of Kerman, Kerman, Iran. \\ ${ }^{2}$ Department of Animal Science, Bila Tserkva National Agrarian University, Bila Tserkva, Ukraine.
}

*Corresponding author: nargesesmaeili91@yahoo.com

doi: 10.15414/jmbfs.2020.9.6.1110-1113

ARTICLE INFO

Received 11. 10. 2018

Revised 11. 1. 2020

Accepted 20. 1.2020

Published 1. 6. 2020

Regular article

open $\mathcal{O}$ access

\begin{abstract}
The aim of this study was to investigate the intron 2 of leptin gene polymorphism in wild, native and exotic goat breeds in Iran using PCR-RFLP. Blood samples were collected from 14 wild and domestic goat breeds including (Cashmere Abadeh, Torki-Ghashghaei, Naeini, Robati, Nadoushani, Adani, Shahrbabaki, Birjandi, China goat, Sannen, Pakistani, Raeini cashmere, Najdi and Wild goat) and then the genomic DNA was extracted. A 422bp fragment from intron 2 of the leptin gene was amplified. PCR products were digested by Sau3AI restriction enzyme and were separated and visualized on the agarose gel. Three genotypes including MM, Mm and $\mathrm{mm}$ with genotype frequency of $94 \%, 1 \%$ and $5 \%$, respectively, were observed in the studied populations. The number of observed alleles, number of the effective alleles, Nei's Index and Shanon's Index were 2, 1.10, 0.09 and 0.19, respectively. The studied populations were not found to be in a Hardy-Weinberg equilibrium. Our investigation demonstrated that MM genotype and $\mathrm{M}$ allele had a very high frequency (0.94 and 0.95 , respectively) in Iranian goats. Hence, it can be concluded that this finding can provide basis for selection when considering evolution and differentiation among breeds, however further studies should be carried out on a larger population of different domestic and wild breeds to verify the final conclusions.
\end{abstract}

Keywords: Diversity, domestic goat, leptin gene, PCR-RFLP, wild goat

\section{INTRODUCTION}

Goat breeding is a growing industry in the world and its products have a desirable landscape (Moghadaszadeh et al., 2015). Despite significant achievements related to the agricultural technology and knowledge of developed countries, but the number of goats has increased in these countries as well (Shamsalddini $\boldsymbol{e} t$ al., 2016). Meat production is the first reason for breeding goats in the world and dairy production is in the next priority. Asia and Africa are the most important goat breeding continents (Mohammadabadi and Tohidinejad, 2017).

According to FAO (2008), about $96 \%$ of the total world goat population are in the developing countries and only $4 \%$ are found in the developed countries (FAO, 2008). There are 30 million heads of cashmere goats around the world and 4.5-5 million heads of them are in Iran that is $16 \%$ of all in the world (Baghizadeh et al., 2009). Goat breeding plays an important and economic role for farmers in the arid and semi-arid regions. Increasing meat production using scientific, and precise selective programs is one of the most important goals of genetic improvement of goats. To identify the genotype of animals and their relationship with productive and reproductive traits, determining the polymorphism and the phylogenetic relationships of domestic animals is also very important (Soufy et al., 2009; Ruzina et al., 2010; Moghbeli et al., 2013; Mohammadabadi \& Tohidinejad, 2017).

Leptin (a product of the $o b$ gene with weight of $16 \mathrm{KD}$ ) was derived from the Greek word leptos (Greek) and encodes for a 167 amino acid. This hormone is mainly produced by the white adipose tissue and to a lesser extent, by muscle cells, stomach epithelium, placenta, fetal tissues, and mammary glands (Gregorio et al. 2014). The most important role of the leptin is to regulate feed intake, energy balance, fertility, and immune functions (Javanmard et al., 2008). This gene has 3 exons and 2 introns, however only 2 exons are translated to protein (Shojaei et al., 2010). The leptin gene is located on the chromosome 4 of the cattle, sheep and goats (Gregorio et al. 2014), and on the chromosome 8 of water buffalo (Gregorio et al. 2014). This gene has both endocrine performance, in the brain and in the various peripheral tissues and also autocrine/paracrine signal within tissues where it is expressed (Zieba et al., 2003). It is demonstrated that leptin is expressed in adipocytes (Chilliard et al., 2001), fetus (Yuen et al.,
2002), breast (Bartha et al., 2005), rumen (Yonekura et al., 2002), small intestine (Yonekura et al., 2002) and hypophysis (Yonekura et al., 2003) of the ruminants. Some effects of this gene are feed intake reduction, body weight loose, lower fat deposits and energy metabolism elevation (Javanmard $\boldsymbol{e t}$ al., 2008). Leptin seems to be important in controlling reproduction through adequite body fat deposits for assisting prosperous conception and pregnancy (Liefers \& Veerkamp, 2002). It is demonstrated that there is direct correlation between plasma level of leptin and body fat mass and energy balance in cattle and sheep (Shojaei et al., 2010). Leptin gene affects the milk performance in cattle and reproduction in beef cattle. According to Bartha et al. (2005), expression of this gene is changed in various physiological and growth stages of animals, hence leptin can be used as a proper marker for evaluating the growth, feed efficiency and health of animals. Celi et al. (2008) showed that plasma and milk leptin concentrations will not be affected by maternal food variation in dairy goats and milk leptin concentration has a negative correlation with kids' liveweights and average daily growth rate. A relatively limited number of studies have been conducted on leptin in goats compared with cattle and in particularIranian wild goats. Therfore, the aim of this study was to study the intron 2 of leptin gene in some Iranian native goat breeds, Iranian imported goat breeds and wild goats.

\section{MATERIALS AND METHODS}

\section{Studied animals}

In this study, 516 blood samples were collected from fourteen different goat breeds (Figure 1) in Iran (Cashmere Abadeh $(\mathrm{CAB}), \mathrm{n}=40$; Torki-Ghahghaei (TOG), n=34; Naeini (NAE), n=30; Robati (ROB), n=28; Nadoushani (NAD), $\mathrm{n}=38$; Adani (ADA), $\mathrm{n}=14$; Shahrbabaki (SHB), $\mathrm{n}=28$; Birjandi (BIR), $\mathrm{n}=34$; China goat (CHI), n=34; Sannen (SAN), n=60; Pakistani (PAK), n=60; Raeini cashmere (RAC), $n=60$; Najdi (NAJ), $n=28$; and Wild goat (capra aegagrus) (WIL), n=28). Wild goat (capra aegagrus) were collected from 3 protected regions and Zoos of Iran (Sistan and Baluchistan, Kerman and Fars provinces). The wild goat is distributed from Europe to Asia (particularly, central Asia and the Middle East). It has been listed as vulnerable on the IUCN Red List since 
1996 (Figure 2). Wild goat (capraaegagrus) is a species of mountain goat. Males are commonly called Kal and have long and sword horns. Blood samples were collected through the jugular vein in K3, EDTA containing tubes to get plasma.

\section{DNA extracting, PCR and gel electrophoresis}

The modified salting-out method (Abadi et al., 2009) was employed to extract genomic DNA. Both spectrophotometry and agarose gel $(1 \%)$ were applied to determine the quality of extracted DNA. A 422-bp fragment within the intron 2 of leptin gene was amplified using PCR primers 5'TGGAGTGGCTTGTTATTTTCTTCT-3' and 5'GTCCCCGCTTTGGCTACCTAACT-3 '(Singh et al., 2009). CinnaGen PCR Master Kit was applied to perform PCR amplification in a $25 \mu \mathrm{l}$ reaction volume, containing negative controls according to the instructions by the manufacturer (CinnaGen Co., Iran). PCR protocol was done at 3 steps: step $1 ; 5 \mathrm{~min}$ at $95^{\circ} \mathrm{C}$, step 2 had 30 cycles consisted of 3 stages; $60 \mathrm{~s}$ at $95^{\circ} \mathrm{C}, 60 \mathrm{~s}$ at $62^{\circ} \mathrm{C}, 60 \mathrm{~s}$ at $72^{\circ} \mathrm{C}$ and step 3 for final extension $5 \mathrm{~min}$ at $72^{\circ} \mathrm{C}$. Electrophores on $1 \%$ agarose gel at constant voltage and $1 \mathrm{X}$ TBE for approximately $2 \mathrm{~h}$ was used for visualization of PCR products. The gels were visualized by ethidium bromide staining and photographed under ultra-violet light. All PCR products were digested with $5 \mathrm{U}$ of $\mathrm{Sau} 3 A \mathrm{I}$ restriction enzyme (Fermentas) at $37^{\circ} \mathrm{C}$ overnight, and the resulting products were separated by the $3 \%$ agarose gel and visualized by ethidium bromide staining.

\section{Data analysis}

Diversity indice including gene diversity $(\mathrm{H})$, observed number of alleles $(\mathrm{Ne})$, Shannon's information index and Nei's index were calculated using POPGEN 3.2 software (Yeh et al., 1999). The animals were cared for in accordance with the local Ethical Committee laws and regulations.

\section{RESULTS AND DISCUSSION}

The extracted DNA had a good quality (Figure 3) and its concentration was approximately 100 nanograms per microlitters. The tested DNA of the goats in our study was amplified by the specific primers and yielded PCR products at the expected size of $422 \mathrm{bp}$ (Figure 4). Amplification of the leptin gene produced 422 $\mathrm{bp}$ fragments. After digesting these fragments with the restriction enzyme Sau3AI, the MM genotype produced two bands: 390 and 32 bp (one restriction site in the $\mathrm{M}$ allele), the mm genotype produced three bands: 303,88 and $32 \mathrm{bp}$ (two restriction sites in the $\mathrm{m}$ allele), and the Mm produced four bands: 390, 303, 88 and 32 bp (heterozygote genotype).

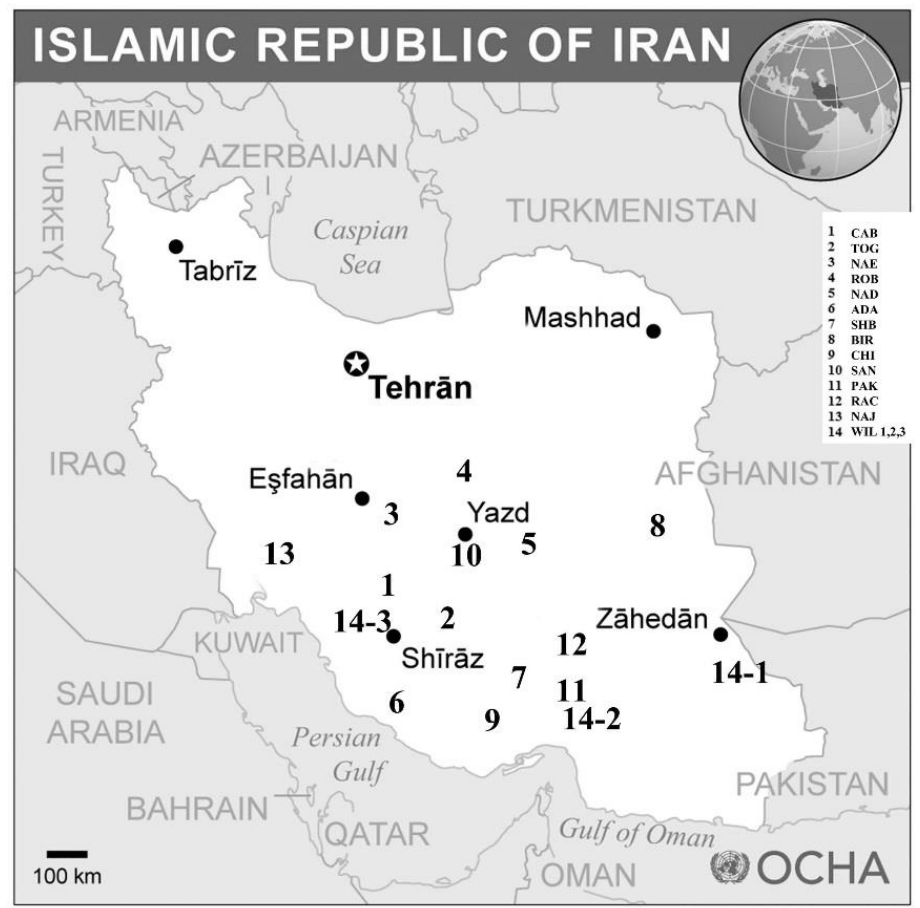

Map Sources: ESRI, UNCS

The boundaries and names shown and the designations used on this map do not imply official endorsement or acceptance by the United Nations. Map created in Sep 2013.

Figure 1 Location of the fourteen study sites in Iran. The putative subspecies are indicated as Cashmere Abadeh (CAB), Torki-Ghahghaei (TOG), Naeini (NAE), Robati (ROB), Nadoushani (NAD), Adani (ADA), Shahrbabaki (SHB), Birjandi (BIR), China goat (CHI), Sannen (SAN), Pakistani (PAK), Raeini cashmere (RAC), Najdi (NAJ), and Wild goat (WIL-1, 2 and 3).
The different alleles from the digestion of the PCR products with the Sau3AI restriction enzyme after running on the agarose gel electrophoresis are presented in Figure 5. Different genotypic and allelic frequencies of leptin gene were observed in the various breeds (Table 1). In this study, the Hardy Weinberg equilibrium was estimated with Chi-square and G-square tests. The studied populations were not found to be in a Hardy-Weinberg equilibrium $(\mathrm{P}<0.05)$.

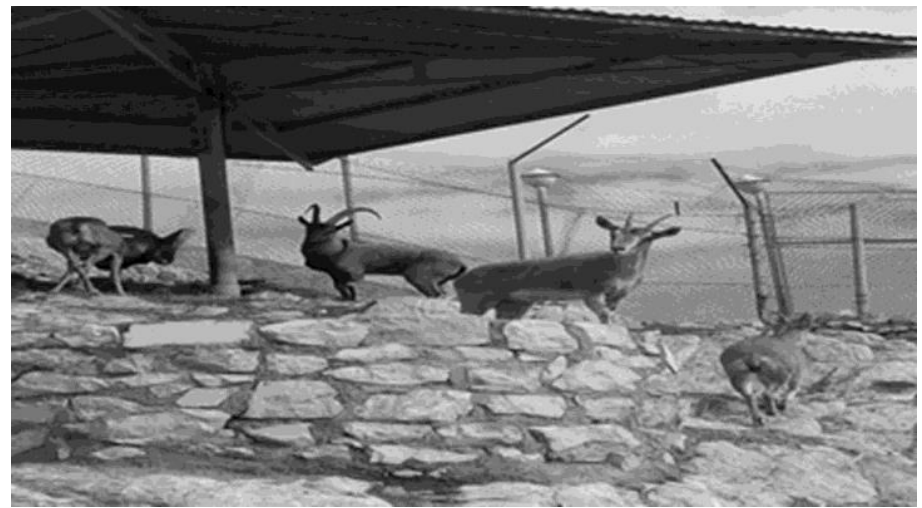

Figure 2 Iranian wild goat.

The values of the population genetics parameters in the studied polymorph breeds have been shown in Table 2. Cashmere Abadeh, Naeini, Robati, Adani, Shahrbabaki, China, Raeini cashmere, Torki-Ghahghaei, Nadoushani, Birjandi, Najdi and Wild breeds were monomorph based on intron 2 of leptin gene. A UPGMA dendrogram based on the Nei's standard genetic distance among studied animals has been shown in figure 6 .

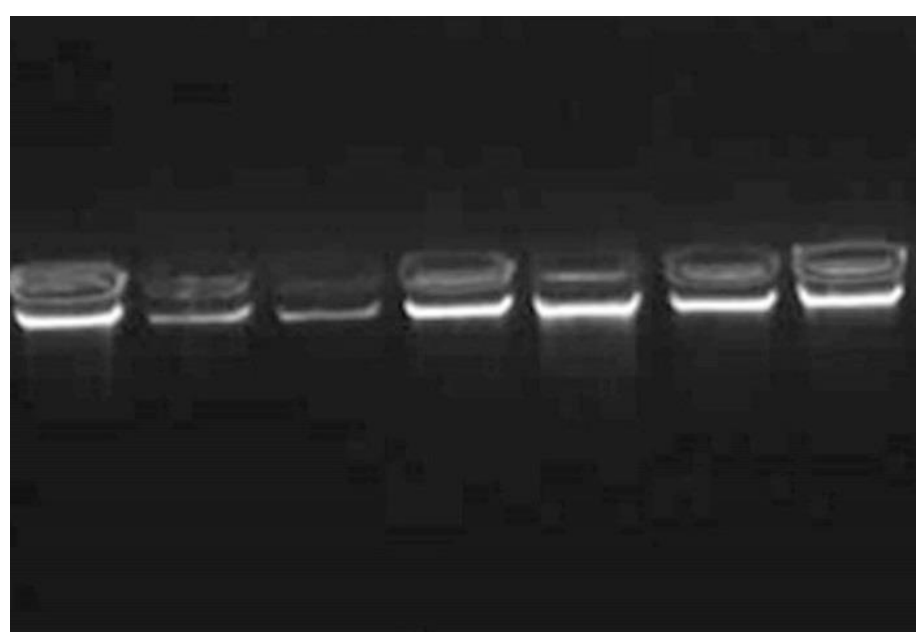

Figure 3 The extracted DNA from the studied animals on the 1\% agarose gel

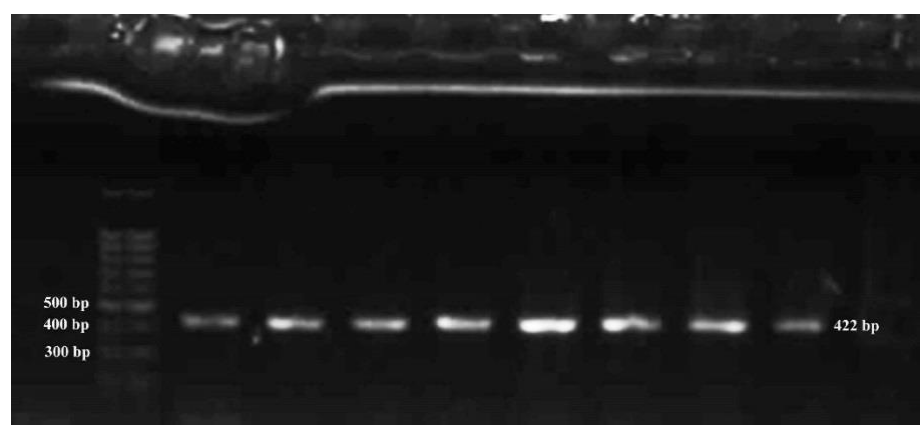

Figure 4 Ethidiumbromide-stained agarose gel of amplified PCR products representing amplification of intron 2 of leptin gene in some studied goats. 


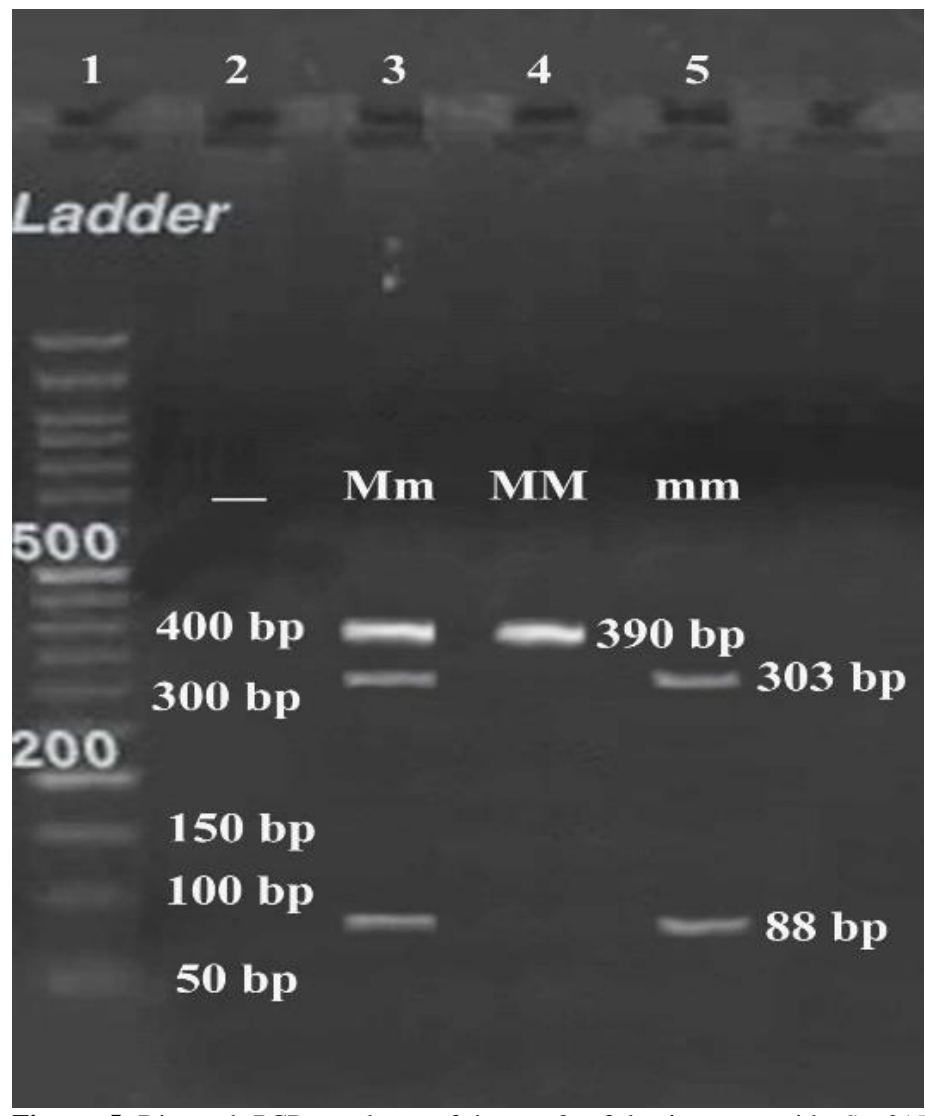

Figure 5 Digested PCR products of intron 2 of leptin gene with $\operatorname{Sau} 3 A$ restriction enzyme in some studied goats. Lane 1 is ladder M50, lane 2 is negative control, lane 3 is Mm genotype, lane 4 is MM genotype and lane 5 is mm genotype.

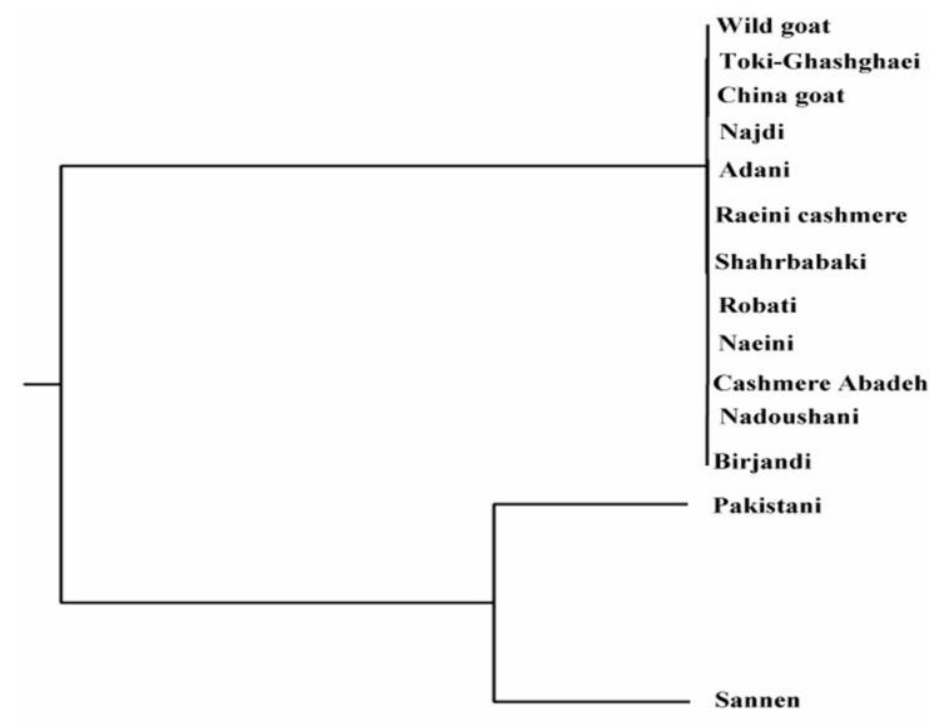

5

Figure 6 UPGMA phylogenetic tree based on Nei genetic distance.

Based on UPGMA phylogenetic tree, breeds including Cashmere Abadeh, Naeini, Robati, Adani, Shahrbabaki, China, Raeini cashmere,Torki-Ghahghaei, Nadoushani, Birjandi, Najdi and Wild breeds were clustered in the same branch and Sannen and Pakistani were clustered in a separate branch from the other breeds. Results of UPGMA phylogenetic tree showed that the two breeds; Sannen and Pakistani breeds that clustered separately from the other ten breeds are genetically different from the rest breeds. The reason for this could be the origin of these two breeds, mutation or selection. The frequencies of leptin alleles in 14 studied breeds showed that frequency of $\mathrm{M}$ allele is higher than frequency of $\mathrm{m}$ allele. The low frequency of allele $\mathrm{m}$ as observed in the 516 different domestic and wild goats of our study is consistent with the results of other researchers (Kulig et al. 2001; Korwin-Kossakowska et al. 2002; Kmieć et al. 2003; Kolodziej et al., 2009).

Three genotypes (MM, Mm and $\mathrm{mm}$ ) were observed in 14 studied domestic and wild populations. These results, in terms of genotype number were similar to results of other researchers on leptin gene (Křenková et al. 1999; Kulig et al. 2001; Korwin-Kossakowska et al. 2002; Kmieć et al. 2003; Kołodziej et al., 2009), although some of these researchers reported only two genotypes from three possible genotypes.

Table 1 Genotypic and allelic frequencies of intron 2 of leptin gene in studied goats

\begin{tabular}{lccccc}
\hline Breed & Genotype & $\mathrm{N}$ & $\begin{array}{c}\text { Genotypic } \\
\text { frequency }\end{array}$ & Allele & $\begin{array}{c}\text { Allelic } \\
\text { frequency }\end{array}$ \\
\hline $\begin{array}{l}\text { Cashmere Abadeh } \\
\text { (CAB) }\end{array}$ & $\mathrm{MM}$ & 40 & 1.00 & $\mathrm{M}$ & 1.00 \\
$\begin{array}{l}\text { Torki-Ghahghaei } \\
\text { (TOG) }\end{array}$ & $\mathrm{MM}$ & 34 & 1.00 & $\mathrm{M}$ & 1.00 \\
Naeini (NAE) & $\mathrm{MM}$ & 30 & 1.00 & $\mathrm{M}$ & 1.00 \\
Robati (ROB) & $\mathrm{MM}$ & 28 & 1.00 & $\mathrm{M}$ & 1.00 \\
Nadoushani (NAD) & $\mathrm{MM}$ & 38 & 1.00 & $\mathrm{M}$ & 1.00 \\
Adani (ADA) & $\mathrm{MM}$ & 14 & 1.00 & $\mathrm{M}$ & 1.00 \\
Shahrbabaki (SHB) & $\mathrm{MM}$ & 28 & 1.00 & $\mathrm{M}$ & 1.00 \\
Birjandi (BIR) & $\mathrm{MM}$ & 34 & 1.00 & $\mathrm{M}$ & 1.00 \\
China goat (CHI) & $\mathrm{MM}$ & 34 & 1.00 & $\mathrm{M}$ & 1.00 \\
& $\mathrm{MM}$ & 34 & 0.57 & & \\
Sannen (SAN) & $\mathrm{Mm}$ & 4 & 0.07 & $\mathrm{M}$ & 0.60 \\
& $\mathrm{~mm}$ & 22 & 0.36 & $\mathrm{~m}$ & 0.40 \\
Pakistani (PAK) & $\mathrm{MM}$ & 58 & 0.97 & $\mathrm{M}$ & 0.97 \\
Raeini cashmere & $\mathrm{mm}$ & 2 & 0.03 & $\mathrm{~m}$ & 0.03 \\
(RAC) & $\mathrm{MM}$ & 60 & 1.00 & $\mathrm{M}$ & 1.00 \\
Najdi (NAJ) & $\mathrm{MM}$ & 28 & 1.00 & $\mathrm{M}$ & 1.00 \\
Wild goat (WIL-1, & $\mathrm{MM}$ & 28 & 1.00 & $\mathrm{M}$ & 1.00 \\
& $\mathrm{MM}$ & 488 & 0.94 & & \\
All and 3) & $\mathrm{Mm}$ & 24 & 0.01 & $\mathrm{M}$ & 0.95 \\
& & & & $\mathrm{~m}$ & 0.05 \\
\hline
\end{tabular}

Table 2 The values of the population genetics parameters in studied goats

\begin{tabular}{lcccc}
\hline Breed & $\begin{array}{c}\text { Number } \\
\text { of } \\
\text { observed } \\
\text { alleles }\end{array}$ & $\begin{array}{c}\text { Number of } \\
\text { effective } \\
\text { alleles }\end{array}$ & $\begin{array}{c}\text { Nei's } \\
\text { Index }\end{array}$ & $\begin{array}{c}\text { Shanon's } \\
\text { Index }\end{array}$ \\
\hline Sannen (SAN) & 2 & 1.92 & 0.48 & 0.67 \\
Pakistani (PAK) & 2 & 1.06 & 0.07 & 0.14 \\
All & 2 & 1.10 & 0.09 & 0.19 \\
\hline
\end{tabular}

In the current study, we observed only one genotype (MM) in the 12 of 14 studied breeds, similar to the wild breed. This might be explained by the originatation of Iranian domestic breeds from the wild breed, which have conserved their genotype for intron 2 of leptin. Furthermore, the low number of the studied samples might also influence the distribution of MM genotype as observed in our study. So it is suggested to investigate more samples from any intact breeds which were kept seperatedly. Our results implied that the studied breeds have a very suitable gene pool for the selection and breeding programs in regards to improving the desired traits. According to Askeri et al. (2011), high genetic diversity is the most important factor for the animal genetic improvement Vitali et al. (2005) showed that body weight, body fat deposits and diet quality affect the onset of puberty in goats, but not the plasma leptin levels. They also concluded that higher plasma leptin during the onset of the puberty maybe operates as permissive sympom for developing the sexual maturity, which can be applied as a detecting instrument to predict the imminent approaching of the event. In another study, Maitra et al. (2014) identified and characterised leptin gene polymorphism and whole sequence in Indian goats. They analysed the sequences using bioinformatics procedures and reported 22 variations in comparison to the exotic goats. In this study, seven SNPs were detected among the 22 variations in exon 2 (g.1029T C), intron 2 (g.1621G_A) and 3'UTR (g.3968T_C, g.3971C_T, g.4026G_A, g.4105G_A and g.4225T_C). These researchers demonstrated that part of the meat quality and tenderness polymorphism in the Indian goat populations is under the effect of the seven detected novel SNPs in the leptin gene. They also concluded that the relationship between theses novel SNPs and the meat quality trait in the animal breeding can be used as a basis for the subsequent precise investigation of leptin genotype correlation with performance. Gregorio et al. (2014) compared leptin gene in goats, sheep, cattle and water buffalos and also evaluated the effects of the Intron 
1 microsatellite polymorphism in goats and showed that leptin gene can be used as a proper marker for studying the metabolism and mammary gland health in dairy goats.

\section{CONCLUSION}

The results of our investigation demonstrated that MM genotype and $\mathrm{M}$ allele have a very high frequency ( 0.94 and 0.95 , respectively) in goats bred in Iran, hence this finding could provide basis information for animal selection when considering evolution and differentiation among breeds. Taking into account all aspects and results, goat leptin gene can be useful for achieving genetic relationship of goat breeds and the selection of economic traits. Considering the observed differences between the results of our study and others, it can be concluded that more investigation is needed to perform on leptin gene polymorphism and its effects on the important traits to verify the final conclusions.

\section{REFERENCES}

Abadi, M.R.M., Askari, N., Baghizadeh, A. \&Esmailizadeh, A. K. (2011). A directed search around caprine candidate loci provided evidence for microsatellites linkage to growth and cashmere yield in Rayini goats. Small Ruminant Research,81, 146-151. URL: https://doi.org/10.1016/j.smallrumres.2008.12.012.

Baghizadeh, A., Bahaaddini, M., Mohamadabadi, M.R. \&Askari, N. (2009) Allelic variations in exon 2 of Caprine MHC class II DRB3 gene in Raeini Cashmere goat. American-Eurasian Journal of Agricultural \& Environmental Sciences 6, 454-459. URL: https://doi.org/10.5829/idosi.aejaes.

Bartha, T., Sayed Ahmed, A. \& Rudas, P. (2005). Expression of leptin and its receptors in various tissues of ruminants. Domestic Animal Endocrinology, 29 193-202. URL: https://doi.org/10.1016/j.domaniend.2005.03.010.

Celi, P., Di Trana, A. \& Claps, S. (2008). Effects of perinatal nutrition on lactational performance, metabolic and hormonal profiles of dairy goats and respective kids. Small Ruminant Research,79, 129-136. URL: https://doi.org/10.1016/j.smallrumres.2008.07.010.

Chilliard, Y., Bonnet, M., Delavaud, C., Fauconnier, Y. \&Leroux,C. (2001). Leptin in ruminants. Gene expression in adipose tissue and mammary gland regulation of plasma concentration. Domestic Animal Endocrinology, 21, 271 295. URL: https://doi.org/10.1016/S0739-7240(01)00124-2.

Gregorio, P.D., Trana, A.D.A., Celi, P., Claps, S. \& Rando, A. (2014) Comparison of goat, sheep, cattle and water buffalo leptin (LEP) genes and effects of the Intron 1 microsatellite polymorphism in goats. Animal Production Science,54, 1258-1262. URL: https://doi.org/10.1071/AN14101.

Javanmard, A., Mohammadabadi, M.R., Zarrigabayi, G.E., Gharahedaghi, A.A. Nassiry, M.R., Javadmansh, A. \&Asadzadeh, N. (2008). Polymorphism within the intron region of the bovine leptin gene in Iranian Sarabi cattle (Iranian Bostaurus). Russian Journal of Genetics,44, 495-497. URL: https://doi:10.1134/S1022795408040169.

Kmieć, M., Kulig, H. \&Konik, A. (2003). Preliminary results on association between leptin gene (LEP) and some reproduction performance traits of boars. Archives Animal Breeding,46, 63-70. URL: https://doi.org/10.5194/aab-46-632003.

Kołodziej, A., Pietruszka, A., Jacyno, E.,Kawęcka, M., Stępień-Poleszak, D. \&Sobocińska, A. (2009). The leptin gene polymorphism and the production traits in the young boars. Zootechnica, 8, 11-18. URL: https://doi.org/10.1111/j.14390388.2006.00611.x.

Korwin-Kossakowska, A., Kamyczek, M., Cieślak, D., Pierzchała, M. \&Kurył, J (2002). The effect of the polymorphism of leptin (LEP), leptin receptor (LEPR) and osteopontin (OPN) genes on selected reproduction traits of synthetic Line 990 sows. Animal Science Papers and Reports,20, 159-168. URL: https://doi.org/10.1046/j.1439-0388.2003.00386.x.

Křenková, L., Kuciel, J. \& Urban, T. (1999). Association of the RYR1, GH, LEP and TF Genes with carcass and meat quality traits in pigs. Czech Journal of Animal Science,44, 481-486. URL: https://doi.org/10.2754/avb201079020243.

Kulig, H., Grzesiak, W. \&Szatkowska I. (2001). Effect of leptin gene polymorphism on growth and carcass traits in pigs. Archives Animal Breeding,44, 291-296. URL: https://doi.org/10.5194/aab-44-291-2001.

Liefers, S.C. \&Veerkamp, R.F. (2002). Association between leptin gene polymorphism and production, live weight energy balance, feed intake and fertility in Holstein heifers. Journal of Dairy Science,85, 1633-1638. URL: https://doi.org/10.3168/jds.s0022-0302(02)74235-5.

Maitra, A., Sharma, R., Pandey, A.K., Singh, L.V., Mandakmale, S.D. \& Mishra, B.P. (2014). Preliminary identification and characterisation of leptin gene polymorphism in Indian goats. Journal of Applied Animal Research,42, 118-122. URL: https://doi.org/10.1080/09712119.2013.795895.

Moghadaszadeh, M., Mohammadabadi, M.R. \&Esmailizadeh, A.K. (2015) Association of Exon 2 of BMP15 gene with the litter size in the Raini Cashmere goat. Genetics in the $3^{\text {rd }}$. Millennium, 13, 4062-4067. URL: https://www.researchgate.net/publication/285912928 Association of Exon 2 of _BMP15_Gene_with_the_Litter_Size_in_the_Raini_Cashmere_Goat.
Mohammadabadi, M.R. \&Tohidinejad, F. 2017. Charachteristics determination of Rheb gene and protein in Raini Cashmere goat. Iranian Journal of Applied Animal Science,7, 289-295. URL: http://ijas.iaurasht.ac.ir/article 531213.html. Moghbeli, S.M., Barazandeh, A., Vatankhah, M. \&Mohammadabadi, M.R. (2013). Genetics and non-genetics parameters of body weight for post-weaning traits in Raini Cashmere goats. Tropical Animal Health and Production, 45, 1519-1524. URL: https://doi.org/10.1007/s11250-013-0393-4.

Ruzina, M.N., Shtyfurko, T.A., Mohammadabadi, M.R., Gendzhieva, O.B., Tsedev, T. \&Sulimova, G.E. (2010). Polymorphism of the BoLA-DRB3 gene in the Mongolian, Kalmyk, and Yakut cattle breeds. Russian Journal of Genetics,46, 456-463. URL: https://doi.org/10.1134/s1022795410040113.

Shamsalddini, S., Mohammadabadi, M.R. \&Esmailizadeh, A. K. (2016) Polymorphism of the Prolactin gene and its effect on fiber traits in goat. Russian Journal of Genetics,52, 405-408. URL: https://doi.org/10.7868/s0016675816040093.

Shojaei, M., Mohammadabadi, M.R., AsadiFozi M., Dayani, O. \&Khezri, A. (2010). Association of growth trait and Leptin gene polymorphism in Kermani sheep. Journal of Cell and Molecular Research,2, 67-73. URL: https://doi.org/10.22067/jcmr.v2i2.3117.

Singh, S.K., Rout, P.K., Agarwal, R., Mandal, A., Singh, S.K., Shukla, S.N. \&Roy, R. (2009). Characterization of Exon 2 and Intron 2 of Leptin Gene in Indian Goats. Animal Biotechnology,20, 80-85. URL: https://doi.org/10.1080/10495390902823885.

Soufy, B., Mohammadabadi, M.R., Shojaeyan, K., Baghizadeh, A., Ferasaty, S., Askari, N. \&Dayani, O. (2009). Evaluation of Myostatin gene polymorphism in Sanjabi sheep by PCR-RFLP method. Animal Science Research,19, 81-89 (In Persian, English abstract). URL: https://www.researchgate.net/publication/234073536_Evaluation_of_Myostatin Gene Polymorphism in Sanjabi_Sheep by PCR-RFLP_Method.

Vitali, A., Magistrelli, D., Azevedo, J., Bernabucci, U., Ronchi, B. \&Rosi, F (2005). Leptin and puberty in goat. Italian Journal of Animal Science, 4, 383-385 URL: https://doi.org/10.4081/ijas.2005.2s.383.

Yeh, F.C., Yang, R.C. \& Boyle, T. (1999). POPGENE, Microsoft Windowsbased freeware for population genetic analysis. Release 1.31. Canada: University of Alberta, Gilmour. https://www.scienceopen.com/document?vid=76d06904-138c-442e-8da73e9fbd47b3cd.

Yonekura, S., Kitade, K., Furukawa, G., Takahashi, K. \& Katsumata, N. (2002). Effects of aging and weaning on mRNA expression of leptin and CCK receptors in the calf rumen and abomasum. Domestic Animal Endocrinology, 22, 25-35. URL: https://doi.org/10.1016/s0739-7240(01)00114-X.

Yonekura, S., Senoo, T., Kobayashi, Y., Yonezawa, T. \&Katoh, K. (2003). Effect of acetate and butyrate on the expression of leptin and short form leptin receptor in bovine and rat anterior pituitary cells. General and Comparative Endocrinology, 133, 165-172. URL: https://doi.org/10.1016/s00166480(03)00162-X.

Yuen, B.S., Owens, P.C., McFarlane, J.R., Symonds, M.E. \& Edwards, L.J (2002). Circulating leptin concentration are positively related to leptin messenger RNA expression in adipose tissue of fetal sheep in pregnant ewe fed at or below maintenance requirements during late gestation. Biology of Reproduction, 67, 911-916. URL: https://doi.org/10.1095/biolreprod.101.002931.

Zieba, A.D., Amstalden, M., Morton, S., Gallino J.L. \& Edwards J.F. (2003) Effects of leptin on basal and GHRH-stimulated GH secretion from the bovine adenohypophysis are dependent upon nutritional status. Journal of Endocrinology, 178, 83-89. URL: https://doi.org/10.1677/joe.0.1780083. 